\title{
Tibialis anterior muscle hernia: a rare differential of a soft tissue tumour
}

\author{
Arunkumar Govindarajan, ${ }^{1}$ Ajith Inigo ${ }^{2}$
}

${ }^{1}$ Department of Radiology, Aarthi Education and Research Foundation, Chennai, Tamil Nadu, India

${ }^{2}$ Rhock Hospital, Tirunelveli, Tamil Nadu, India

\section{Correspondence to} Dr Arunkumar Govindarajan, arun.amigo@gmail.com

Accepted 3 September 2015
CrossMark

To cite: Govindarajan A, Inigo A. BMJ Case Rep Published online: [please include Day Month Year] doi:10.1136/bcr-2015-

212462

\section{DESCRIPTION}

A 57-year-old man with a history of fall injury presented with swelling in the anterior aspect of his left leg, with occasional pain while walking. On examination, the swelling had a rubbery consistency and was partly reducible. The swelling increased in size on standing and activity. Differentials including superficial varicosity, vascular malformation, muscle hernia and soft tissue tumour were considered and MRI was carried out.

MRI showed protrusion of the tibialis anterior through a focal defect in fascia overlying the muscle (figure 1). The defect measured $1.5 \times 1.4 \mathrm{~cm}$. There was a subtle $\mathrm{T} 2$ and short $\tau$ inversion recovery hyperintense signal within the herniated muscle, possibly due to oedema (figures 2 and 3). A diagnosis of tibialis anterior muscle hernia was confirmed and the patient was managed with compression stockings and activity restriction.

Ihde ${ }^{1}$ classified the aetiology of muscle hernias into traumatic and constitutional (generalised weakness of fascia). In the lower limb, the most commonly involved muscle is the tibialis anterior due to its weak and vulnerable fascia. A dynamic ultrasonogram or MRI can confirm the diagnosis. ${ }^{2}$ The treatment of muscle hernias depends on the severity of symptoms. While they can be managed

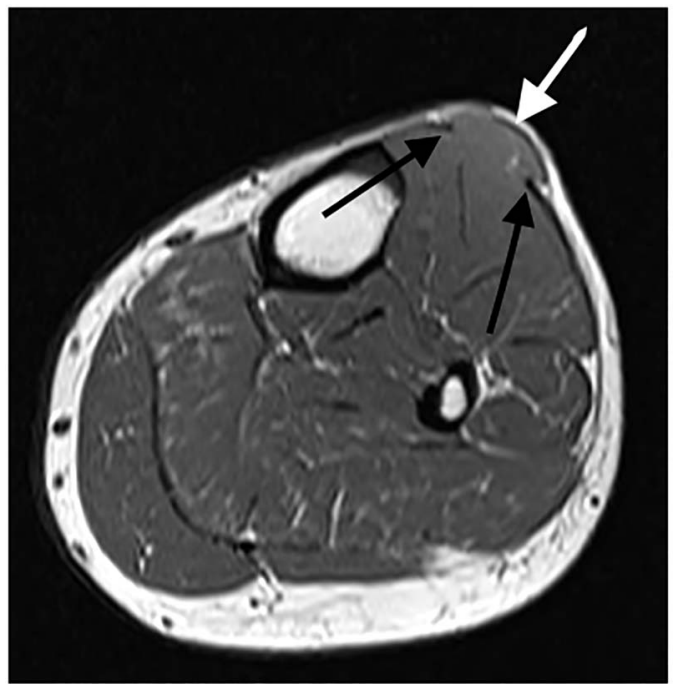

Figure 1 Axial T1 image showing protrusion of the tibialis anterior muscle (white arrow) through a focal defect in the overlying fascia (black arrows).

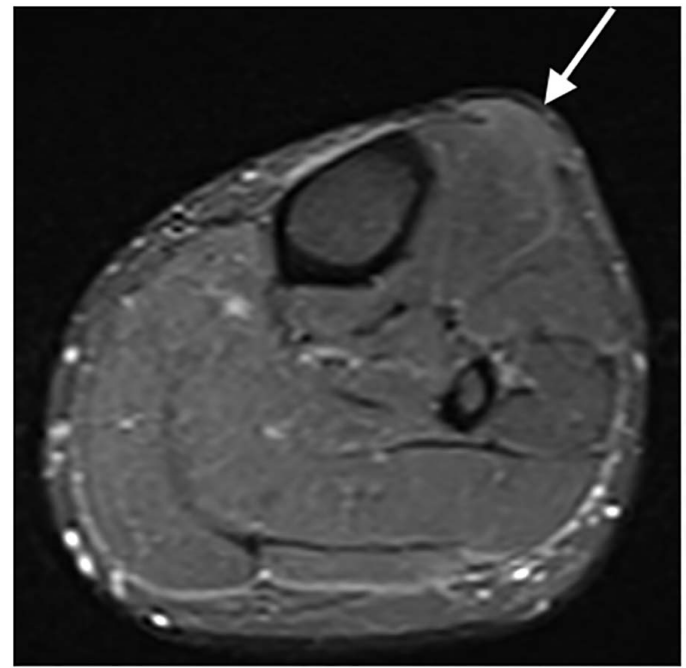

Figure 2 Axial short $\tau$ inversion recovery image showing subtle hyperintensity within the herniated muscle (white arrow), representing oedema.

conservatively with compression stockings and activity restriction, persistently symptomatic muscle hernias need longitudinal fasciotomy. ${ }^{2}$

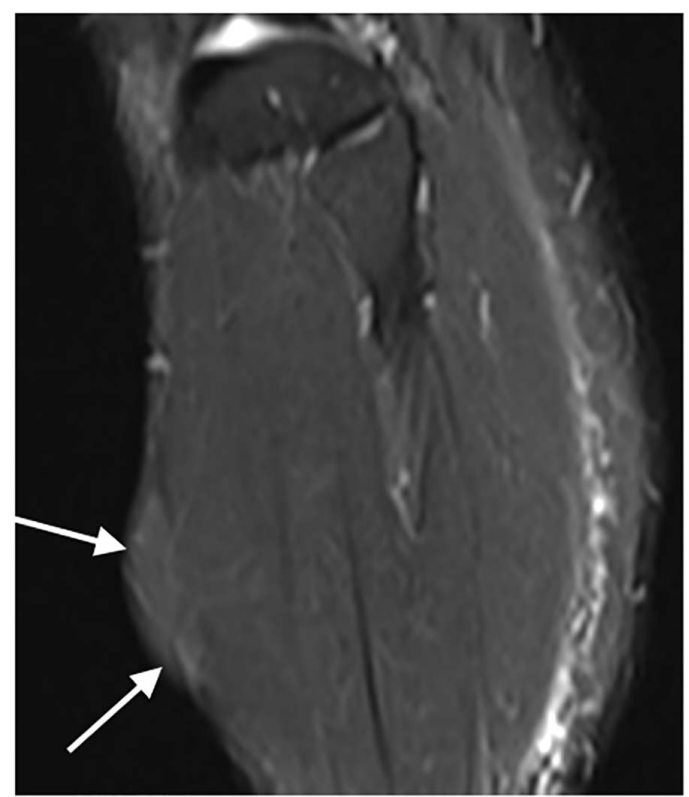

Figure 3 Sagittal short $\tau$ inversion recovery image showing protrusion of the subtly hyperintense muscle (white arrow) through the defect. 


\section{Learning points}

- Muscle hernia should be considered in the differential of reducible or compressible soft tissue mass.

- Muscle hernias increase in size on activity and standing.

- Dynamic ultrasonogram or MRI can demonstrate the focal fascial defect and the muscle protrusion through it.
Competing interests None declared.

Patient consent Obtained.

Provenance and peer review Not commissioned; externally peer reviewed.

\section{REFERENCES}

1 Inde H. On muscular hernia of the leg. Acta Chir Scand 1929;65:97-120.

2 Nguyen JT, Nguyen JL, Wheatley MJ, et al. Muscle hernias of the leg: a case report and comprehensive review of the literature. Can J Plast Surg 2013;21:243-7.

Contributors AG participated in interpretation of radiological data, reviewed the scientific literature, and drafted and finalised the manuscript. Al supervised the article design, and critically evaluated and finalised the article.

Copyright 2015 BMJ Publishing Group. All rights reserved. For permission to reuse any of this content visit http://group.bmj.com/group/rights-licensing/permissions.

BMJ Case Report Fellows may re-use this article for personal use and teaching without any further permission.

Become a Fellow of BMJ Case Reports today and you can:

- Submit as many cases as you like

- Enjoy fast sympathetic peer review and rapid publication of accepted articles

- Access all the published articles

- Re-use any of the published material for personal use and teaching without further permission

For information on Institutional Fellowships contact consortiasales@bmjgroup.com

Visit casereports.bmj.com for more articles like this and to become a Fellow 